\title{
Breeding Habitat Selection of Reeves's Pheasant (Syrmaticus reevesii) in Dongzhai National Nature Reserve, Henan Province, China
}

\author{
XU Ji-Liang ${ }^{1,2}$, ZHANG Xiao-Hui ${ }^{2}$, ZHANG Zheng-Wang ${ }^{2, *}$, ZHENG Guang-Mei ${ }^{2}$, \\ RUAN Xiang-Feng ${ }^{3}$, ZHANG Ke-Yin ${ }^{3}, \mathrm{XI} \mathrm{Bo}^{3}$ \\ (1. College of Nature Conservation, Beijing Forestry University, Beijing 100083, China; 2. Ministry of Education Key Laboratory for Biodiversity \\ Sciences and Ecological Engineering; College of Life Sciences, Beijing Normal University, Beijing 100875, China; \\ 3. Dongzhai National Nature Reserve, Segang, Henan 464236, China)
}

\begin{abstract}
Reeves's Pheasant (Syrmaticus reevesii) is a threatened pheasant species endemic to China. The habitat use of territorial male birds was surveyed by the help of live decoys in a core area of Dongzhai National Nature Reserve. The breeding habitat selection of this pheasant was examined at two scales $\left(115 \mathrm{~m}\right.$ and $250 \mathrm{~m}$ scale, i.e. $4.15 \mathrm{hm}^{2}$ and 19.63 $\mathrm{hm}^{2}$, respectively), including the characteristics at distance scale. Investigation was based on line transect, RS and GIS in Dongzhai National Natural Reserve from 2001 to 2003. Moreover, a range of habitat variables were compared between used and control points at each scale, and stepwise logistic regression was applied to select the key scale and the key habitat factors in relation to breeding habitat selection of this bird. Our results stated that the territorial males at Baiyun occurred mostly in mixed forests, followed by fir forests, pine forests, shrubs, and broadleaf forests. The area of conifer forests was the key factor influencing habitat selection of this bird in breeding period at the scales of $115 \mathrm{~m}$ and $250 \mathrm{~m}$, and the proximity of farmland was important for habitat selection in breeding seasons. Furthermore, Reeves's Pheasants attached great importance to the scale of $115 \mathrm{~m}$. When considering a range of habitat variables at all scales within a multivariate regression, the leading factors having effect on habitat selection in the breeding period were areas of conifer forests at $115 \mathrm{~m}$ scale and the distance to farmland. In addition, these above results suggested that strengthening the management of suitable habitat, and optimizing the habitat configuration are important in promoting conservation of this bird. However, it also highlighted the importance of initiating future researches on the conifer forests and their impact on the population of Reeves's Pheasants, which would be beneficial to promote the habitat conservation of this pheasant more effectively.
\end{abstract}

Key words: Syrmaticus reevesii; Breeding period; Habitat selection

\section{河南董寨白冠长尾雉繁殖期栖息地选择}

\author{
徐基良 ${ }^{1,2}$, 张晓辉 ${ }^{2}$, 张正旺 ${ }^{2, *}$, 郑光美 ${ }^{2}$, 阮祥锋 ${ }^{3}$, 张可银 ${ }^{3}$, 溪 波 $^{3}$ \\ (1. 北京林业大学 自然保护区学院, 北京 $100083 ; 2$. 北京师范大学 生物多样性与生态工程教育部重点实验室; \\ 生命科学学院, 北京 100875 ; 3. 董寨国家级自然保护区, 河南 灵山 464236)
}

摘要: 2001 年至 2003 年春季, 采用样线调查和媒鸟招引, 在河南董寨国家级自然保护区对我国特有珍稀雉 类白冠长尾雉 (Syrmaticus reevesii) 的栖息地选择进行了调查, 结合 RS 和 GIS 分析了在景观水平上对栖息地的选 择性, 并借助逐步逻辑斯谛回归分析了影响繁殖期白冠长尾雉栖息地的关键尺度和主要因素。结果表明, 在白云 保护站, 占区雄性白冠长尾雉在不同栖息地类型中的出现频率不同, 出现最多的是混交林, 其次是杉木林, 随后 是松林、灌丛、阔叶林; 在董寨自然保护区内, 在 $115 \mathrm{~m}$ 尺度和 $250 \mathrm{~m}$ 尺度上, 针叶林的面积比例均是影响其栖 息地选择的关键因子, 而到农田的距离是距离因素中最重要的因素。根据回归分析和 $A I C_{C}$ 及 $\triangle A I C_{C}$ 值, $115 \mathrm{~m}$ 尺 度上栖息地变量对白冠长尾雉繁殖期的栖息地选择影响最大。综合分析表明, 影响白冠长尾雉繁殖期栖息地选择 的主要因子为 $115 \mathrm{~m}$ 尺度上针叶林的面积比例和到农田的距离。建议在制定白冠长尾雉栖息地保护策略时, 应加

Received date: 2009-12-22; Accepted date: 2010-03-15

"Corresponding author(通讯作者), Tel: +86-10-58809666; Fax: +86-10-58808998; E-mail: zzw@bnu.edu.cn

收稿日期：2009-12-22；接受日期：2010-03-15

基金项目：国家自然科学基金资助项目（30800103）; 国家科技支撑计划课题（2008BADB0B01） 
强现有适宜栖息地的管理, 改善栖息地布局, 并从景观尺度上开展针叶林对白冠长尾雉种群影响方面的研究工作。 关键词: 白冠长尾雉; 繁殖期; 栖息地选择 中图分类号：文献标识码：A 文章编号：0254-5853-(2010)02-0198-07

The status of pheasant in breeding period played a key role in its life history (Johnsgard, 1999), and the habitat selection in this period had a great effect on the survival rate and reproductivity (Cody, 1985; Badyaev et al, 1996). Some researches (Hill \& Robertson, 1988; Smith et al, 1999; Graves, 2002) also suggested that the information on bird habitat requirements in breeding seasons was important for conservation. Therefore, researches on home range and habitat requirements have been an important part in pheasant research (Cody, 1985; Johnsgard, 1999; Graves, 2002).

Reeves's Pheasant (Syrmaticus reevesii) is a threatened species endemic to China (Cheng, 1978; 1987). This species was widespread and common in central China historically (Cheng, 1978), but populations have been extirpated because of illegal hunting, habitat loss and fragmentation (Xu et al, 1991; Wu et al, 1994; MacKinnon et al, 1996; Zheng \& Wang, 1998). Therefor, it is currently listed as a national second-grade wildlife species of China (Zheng \& Wang, 1998) and as a vulnerable species in the world (IUCN, 2009). Some qualitative researches on the habitat of this pheasant had been carried out in the past (see Wu, 1979; Fang \& Ding, 1997), and some quantitative studies appeared recently (see Sun et al, 2001, 2002; Xu et al, 2002, 2005, 2006), including research on incubation behavior (Zhang et al, 2004), home range, and habitat selection (see Sun et al, 2003; Xu et al, 2007, 2009).

However, very little is known about the habitat selection of Reeves's Pheasant at a landscape scale in breeding seasons for the limitations of study methods, which is particularly useful to its conservation. In this study, we investigated the habitat selection of this pheasant in spring at landscape scale in Dongzhai National Nature Reserve, which may be helpful to make some conservation measures on it.

\section{Study area}

Fieldwork was carried out from 2001 to 2003 in Dongzhai National Nature Reserve $\left(\begin{array}{lll}114^{\circ} & 18^{\prime} & -114^{\circ} 30\end{array}\right.$ ' E, $\left.31^{\circ} 28^{\prime}-32^{\circ} 09^{\prime} \mathrm{N}\right)$, over an area of $45400 \mathrm{hm}^{2}$ located on the northern slopes of the Dabie mountain range, Henan Province, central China. The reserve is situated at the edge of the northern subtropical zone, and is warm and humid. The altitude of this reserve ranges from 100 to $500 \mathrm{~m}$, with the highest peak of the reserve at $827.7 \mathrm{~m}$. The topography of the reserve appears to be higher in the southern and western parts, but lower in the northern and eastern parts. Mean annual temperature is about $15.1{ }^{\circ} \mathrm{C}$, and mean annual precipitation about $1208.7 \mathrm{~mm}$. The vegetation is characterized by the transition between the North and the South, which was described by Sun et al (2001) in detail. Baiyun is one of the core areas of this reserve, occupying an area of 400 $\mathrm{hm}^{2}$, with an altitude ranging from 100 to $446 \mathrm{~m}$.

\section{Methods}

\subsection{Data collection}

2.1.1 Description of habitats Digital habitat maps in Dongzhai National Nature Reserve were produced based on remote sensing images from Sep 1999. According to the resolving power of the images, the plant species present and their coverage, and the possible effects of the vegetation on Reeves's Pheasant obtained from literature and pre-investigation, the habitat in this reserve was classified into shrub, conifer forest, broadleaf forest, water, beach, farmland, resident, unpaved road, and paved road.

A 1: 10000 vegetation map in Baiyun, supplied by the management bureau of the nature reserve was ground-truthed by field observations and digitized to produce a digital map of the study site. The habitats within the main study area were classified according to plant species present and their coverage. The habitat in Baiyun was classified into broadleaf and conifer mixed forest, broadleaf forest, pine forest, farmland, Chinese fir forest, artificial plantation, and shrub, and were described in detail in Xu et al (2007).

Due to limitation of the resolution, and different habitat classification systems between Baiyun and Dongzhai National Nature Reserve, the territorial males in Baiyun and the Reeves's Pheasants in Dongzhai National Nature Reserve were analyzed independently.

2.1.2 Habitat use of territorial males in Baiyun By the help of a decoy, the habitat use of territorial males in Baiyun in Dongzhai National Nature Reserve was studied from 2001 to 2003, with data of 2002 used for further analysis due to higher accuracy. We placed the decoy at 53 sites in the core area in 2002, and the number of the sites in each habitat type was in proportion to the 
area of the corresponding habitat. Moreover, we spent between $0.5-1 \mathrm{~h}$ in each site. The number of males close to the decoy and the habitat types were recorded. Some potentially repeated records were deleted according to radio-tracking and the home range area of males (see Sun et al, 2003). The remaining records were confirmed by line transects in spring from 2001 to 2003.

2.1.3 Used sites of Reeves's Pheasants in breeding seasons in Dongzhai National Nature Reserve Line transects were used to survey the distribution of Reeves's Pheasant in this reserve before 10:00 am and after 15:00 pm. According to the former investigation, Reeves's Pheasant concentrated in the core area of this reserve, and Ring-necked Pheasant mainly appeared in the experiment area and the village surroundings. Therefore, the used sites of Reeves's Pheasant in the breeding period were investigated in the core area of this reserve, and were determined by the feather, feces, and bathing hole. If an individual was found, the used sites could be determined when it was evident that the observers did not disturb it. The used sites were marked by GPS.

2.1.4 Habitat characteristics According to the used sites of Reeves's Pheasants during the breeding period, a Minimum Convex Polygon (MCP) was obtained. A buffer of $100 \mathrm{~m}$ was established based on the MCP due to some used sites were located on the borderline. The MCP and the buffer composed of the control area. We generated 74 random sites in the control area, and 9 sites were omitted as they were situated in the resident and water area. The used sites, the control sites, and the habitat maps were overlaid. These sites were used as the centres, and then buffers with $115 \mathrm{~m}$ and $250 \mathrm{~m}$ were produced with a radius of $115 \mathrm{~m}$ or $250 \mathrm{~m}$, similar to the home range and core area, respectively. The landscape variables were measured as follows: at $115 \mathrm{~m}$ scale, including area of shrubs, area of conifer forests, and area of broadleaf forests; at $250 \mathrm{~m}$ scale, variables similar to those at $115 \mathrm{~m}$ scale. In addition, distances to water, beach, farmland, resident, unpaved road, and paved road were also measured.

\subsection{Data analysis}

2.2.1 Habitat use of territorial males in Baiyun Chi-square was used to analyze the habitat use of territorial males in Baiyun.

2.2.2 Breeding habitat selection of Reeves's Pheasants in Dongzhai National Nature Reserve MANOVA was used to compare the habitat characteristics of used sites to those of control sites. In order to use MANOVA, some of the data were transformed to fit normal distribution based on the following:

Distance to water: $D W A 1=\ln (D W A+1)$;

Distance to resident: $\quad D R E 1=\ln (D R E+1)$;

Distance to unpaved road: $D U N 1=\ln (D U N+100)$;

Distance to farmland: $D F A 1=\ln (D F A+100)$ 。

Independent samples $t$ tests were used to compare variables of the used sites with those of the control sites if the data were normal, whereas Mann-Whitney $U$ tests were used when the data were not normal. A probability of 0.05 or less was accepted as significant, and the variables remained for further analysis.

For each scale, we used forward elimination stepwise logistic regression (SLR) (Hosmer \& Lemeshow, 1999) to obtain sets of predictors of habitat use by Reeves's Pheasants, and the first-order interactions were also included in the analysis (McGrath et al, 2003). Univariate analysis of the remaining variables and their first-order interactions were performed first. Any variable or first-order interaction whose univariate test has a $p$-value less than 0.25 should be considered as a candidate for further analysis (Hosmer \& Lemeshow, 1999). We then used Spearman's correlation matrix in order to eliminate statistically redundant variables with $|r|>0.70$, but kept all those of bigger deviances, or that were biologically important for Reeves's Pheasant (McGrath et al, 2003). The remaining variables and the first-order interactions were used as the independent variables for the multivariate analysis. Moreover, the distance variables were treated with similar strategies.

According to the regression results, we calculated the $A I C$ and $A I C_{C}$ (Burnham \& Anderson, 1998). The lower the value of $A I C$ or $A I C_{C}$, the more important the factor to the habitat selection of this pheasant (Burnham $\&$ Anderson, 1998; Boyce et al, 2002). AIC or $A I C_{C}$ belongs to the Akaike Information Standard, and now they are used commonly to assess the fit of the model (Burnham and Anderson, 1998; Boyce et al, 2002).

$A I C_{C}$ was used if $n / K<40$ (Burnham and Anderson, 1998), and

$$
A I C_{C}=A I C+2 K(K+1) /(n-K-1)
$$

Where $K=$ the number of the variables in the regression +2 , and $n=$ sample size. 
$\triangle A I C$ or $\triangle A I C_{c}$ was used to selected the best suitable regression result from all results, and it could be calculated by the $A I C$ or $A I C_{C}$ of any result subtracted by the minimum one (Burnham \& Anderson, 2002).

In all statistical tests, a probability of 0.05 or less was accepted as significant. Unless specifically mentioned, means are given as mean $\pm S E$. All statistical procedures were carried out using the software SPSS
10.0 for Windows.

\section{Results}

\subsection{Habitat use of territorial male Reeves's Phea- sant in Baiyun}

Totally, 35 wild male Reeves's Pheasant emerged in 25 sites with a decoy, and averaged $1.40 \pm 0.15$ (Means $\pm 1 S E$.) for each site.

Tab. 1 The distribution and density of territorial male Reeves's Pheasants

\begin{tabular}{lcc}
\hline \multicolumn{1}{c}{ Habitat type } & Area $\left(\mathrm{hm}^{2}\right)$ & Individuals \\
\hline Shrub & 32.28 & 4 \\
Mixed & 183.00 & 15 \\
Broadleaf & 51.12 & 3 \\
Fir & 59.82 & 7 \\
Pine & 21.96 & 6 \\
Replanted & 20.53 & 0 \\
Farmland & 2.32 & 0 \\
\hline
\end{tabular}

Territorial males occurred mostly in broadleaf and conifer mixed forests, and followed by fir forest, pine forest, shrub, and broadleaf forest (Tab. 1). There were no significant differences for the territorial males used the habitat types $\left(\chi^{2}=7.002, d f=5, P=0.221\right)$. However, territorial males used pine forest and shrub a little higher than their available (Fig. 1).

\subsection{Breeding habitat selection of Reeves's Pheasant}

The line transects added up to $27900 \mathrm{~m}$, averaged $(845.46 \pm 46.37) \mathrm{m}(n=33)$. Totally 44 used sites were recorded in the field.

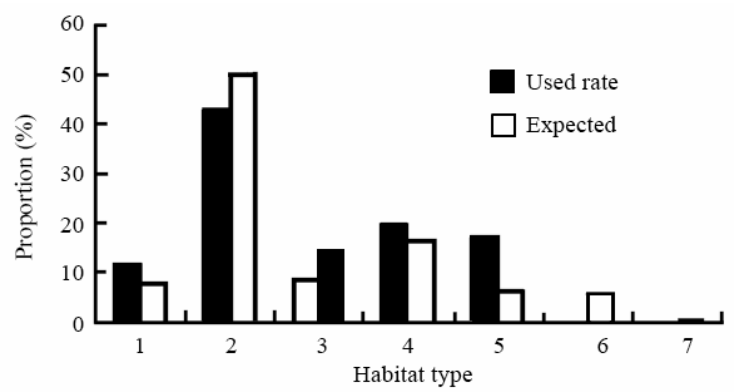

Fig. 1 The proportions of territorial male Reeve's Pheasants in different habitat types in Baiyun in Dongzhai National Natural Reserve, Henan

1: Shrub; 2: Mixed; 3: Broadleaf; 4: Fir; 5: Pine; 6: Replanted; 7: Farmland.

Reeves's Pheasant used habitat non-randomly in breeding period (MANOVA: $F_{12,96}=7.603, P<0.001$ ). At $115 \mathrm{~m}$ and $250 \mathrm{~m}$ scales, Reeves's Pheasant preferred sites with higher broadleaf and conifer forests (Tab. 2).
For distance, Reeves's Pheasant preferred sites far away from water, farmland, resident, and unpaved road (Tab. 2).

By SLR, occurrence of Reeves's Pheasant, at each scale, was associated significantly with conifer forests coverage at $115 \mathrm{~m}$ and $250 \mathrm{~m}$ scale, and it was also influenced significantly with distance to farmland (Tab. 3).

According to the value of $\triangle A I C_{c}$ obtained at each scale, the variables at $115 \mathrm{~m}$ scale was the most important among these scales (Tab. 3). Multivariate analysis suggested that occurrence of Reeves's Pheasant was influenced significantly by conifer forest coverage at $115 \mathrm{~m}$ scale and the distance to farmland.

\section{Discussion}

Some researches have suggested habitat selection of wild animals was scale-dependent (Orians \& Wittenberger, 1990; Kotliar \& Wiens, 1991), and knowledge on habitat selection at only one scale might be biased to reality (Kotliar \& Wiens, 1991). Recently, it was shown that studying habitat at multi-scale was an effective method to understand the actual habitat requirements of wildlife (McGrath et al, 2003; Xu et al, 2006). According to our study on habitat use of Reeves's Pheasant in Dongzhai National Nature Reserve and its core area, i.e. Baiyun, it also demonstrated that Reeves's Pheasant's habitat selection in breeding period was scale-dependent. 
Tab. 2 Comparisons of habitat variables between the used points and the control points for Reeves's Pheasants in breeding period

\begin{tabular}{|c|c|c|c|c|c|}
\hline Habitat variables & $\begin{array}{l}\text { Used points }^{\mathrm{a}} \\
\quad(n=44)\end{array}$ & $\begin{array}{l}\text { Control points }^{\mathrm{a}} \\
\quad(n=65)\end{array}$ & $t$-value & $d f$ & $P$-value \\
\hline \multicolumn{6}{|l|}{$115 \mathrm{~m}$} \\
\hline Area of shrub in a circular with radius of $115 \mathrm{~m}$ (SHR115) (\%) & $32.59 \pm 3.43$ & $38.83 \pm 3.28$ & -1.280 & 107.00 & 0.203 \\
\hline Area of conifer in a circular with radius of $115 \mathrm{~m}(\mathrm{BRO} 115)(\%)$ & $10.93 \pm 1.39$ & $9.24 \pm 1.81$ & $-2.455^{b}$ & & $0.014^{*}$ \\
\hline Area of broadleaf in a circular with radius of $115 \mathrm{~m}(\mathrm{CON} 115)(\%)$ & $53.95 \pm 3.29$ & $26.19 \pm 3.17$ & 5.893 & 107.00 & $0.000^{* *}$ \\
\hline \multicolumn{6}{|l|}{$250 \mathrm{~m}$} \\
\hline Area of shrub in a circular with radius of $250 \mathrm{~m}$ (SHR250) (\%) & $34.28 \pm 2.45$ & $39.79 \pm 2.66$ & -1.525 & 105.59 & 0.130 \\
\hline Area of conifer in a circular with radius of $250 \mathrm{~m}(\mathrm{BRO} 250)(\%)$ & $13.19 \pm 1.41$ & $9.60 \pm 1.58$ & $-3.082^{b}$ & & $0.002^{* *}$ \\
\hline Area of broadleaf in a circular with radius of $250 \mathrm{~m}(\mathrm{CON} 250)(\%)$ & $49.10 \pm 2.49$ & $27.55 \pm 2.79$ & 5.757 & 106.27 & $0.000^{* *}$ \\
\hline \multicolumn{6}{|l|}{ Distance } \\
\hline Distance to water (DWA)(m) & $544.63 \pm 68.51$ & $308.16 \pm 36.31$ & 3.155 & 107.00 & $0.002^{* *}$ \\
\hline Distance to beach (DBE) $(\mathrm{m})$ & $407.01 \pm 28.45$ & $498.99 \pm 39.57$ & -1.887 & 105.37 & 0.062 \\
\hline Distance to farmland (DFA) (m) & $502.04 \pm 51.03$ & $176.05 \pm 30.82$ & 6.168 & 107.00 & $0.000^{* *}$ \\
\hline Distance to resident $(\mathrm{DRE})(\mathrm{m})$ & $268.88 \pm 29.60$ & $192.53 \pm 25.03$ & 2.420 & 107.00 & $0.017^{*}$ \\
\hline Distance to unpaved road (DUN) (m) & $773.33 \pm 70.97$ & $471.04 \pm 51.85$ & 3.725 & 107.00 & $0.000^{* *}$ \\
\hline Distance to highway (DHG) (m) & $1619.70 \pm 147.30$ & $1533.71 \pm 118.41$ & 0.457 & 107.00 & 0.649 \\
\hline
\end{tabular}

Note: a Data were not transformed; B Mann-Whitney $U$ test.

${ }^{*} P<0.05 ;{ }^{* *} P<0.01$.

Tab 3 Stepwise logistic regressions for breeding habitat of Reeves's Pheasants

\begin{tabular}{lllccc}
\hline \multicolumn{1}{c}{ Scales } & \multicolumn{1}{c}{ Habitat types } & $p$ & Percentage correct & AICc & $\Delta A I C c^{*}$ \\
\hline $115 \mathrm{~m}$ & CON115 & 2 & 72.5 & 124.514 & 23.228 \\
$250 \mathrm{~m}$ & CON250 & 2 & 70.6 & 127.679 & 26.363 \\
Distance & DFA1 & 2 & 75.2 & 122.358 & 21.072 \\
$115 \mathrm{~m} \times$ Distance & DFA1, CON115 & 3 & 78.9 & 101.286 & 0 \\
$250 \mathrm{~m} \times$ Distance & DFA1, CON250 & 3 & 79.8 & 105.916 & 4.630 \\
$115 \mathrm{~m} \times 250 \mathrm{~m}$ & CON115 & 2 & 72.5 & 124.514 & 23.228 \\
$115 \mathrm{~m} \times 250 \mathrm{~m} \times$ Distance & CON115, DFA1 & 3 & 78.9 & 101.286 & 0 \\
\hline
\end{tabular}

** The references of the abbreviations in Tab. 2 are same to those in Tab. 2 .

The conifer coverage was analyzed in detail, and Reeves's Pheasant occurred mostly in a proportion ranging from $20 \%$ to $80 \%$ at $115 \mathrm{~m}$ scale, and ranging from $40 \%$ to $60 \%$ at a $250 \mathrm{~m}$ scale (Fig. 2).

Territorial male Reeves's Pheasant occurred mostly in broadleaf and conifer mixed forests, broadleaf forests, fir forests, and pine forests in Baiyun in Dongzhai National Nature Reserve, similar to what was shown in previous reports (Wu et al, 1991; Fang \& Ding, 1997; Xu et al 2007). Compared to Xu et al (2007), however, there existed a small difference. Xu et al (2007) reported that this species preferred shrubby area. This difference should be contributed to the different methods used in these two studies, as Xu et al (2007) used radio telemetry to track the wild individuals in the field, which could reduce human disturbance, while this study had to build a blindage, which might be significant in a shrubby area. However, as an adaptive management approach (Salafsky et al, 2002), these results on territorial males should be useful in Reeves's Pheasant conservation, despite 
some limitations of methods.

Although Fang \& Ding (1997) suggested that Reeves's Pheasant varied in habitat selection across seasons, our results showed that habitat selection of Reeves's Pheasant in breeding period did not differ significantly compared to that in winter (Xu et al, 2006) in the whole Dongzhai National Nature Reserve, which was similar to the seasonal habitat use of this species stated in $\mathrm{Wu}$ (1979), $\mathrm{Hu} \&$ Wang (1981), and Xu et al (2007). For example, Reeves's Pheasant occurrence was negative with the distance to water, farmland, resident, and unpaved road, and it was influenced significantly by the distance to farmland, which was also reported in winter (Xu et al, 2006) and the males radio-tracked (Xu et al, 2005, 2007). The higher site fidelity of this pheasant (Xu et al, 2009) should be responsible for such a habitat use pattern. In addition, this pattern should be helpful to take some measures to conserve this species in this reserve.

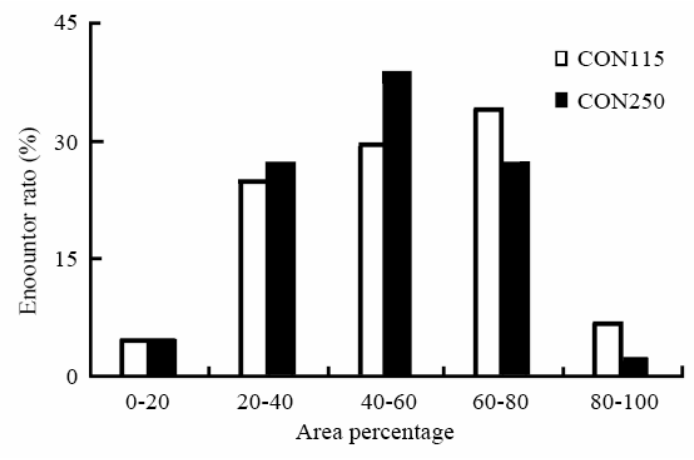

Fig. 2 The relationship between the number of Reeve's Pheasants and the area percentage of conifer forests

McGrath et al (2003) stated that the nest site selection of Eurasian Sparrow Hawk (Accipiter nisus) was influenced by landform at $1 \mathrm{hm}^{2}$ scale, but it was influenced mostly by the features at $30 \mathrm{hm}^{2}$ scale among the six scales larger than $10 \mathrm{hm}^{2}$. Our results also suggested that $115 \mathrm{~m}$ scale was the most important factor for habitat selection of Reeves' pheasant in breeding seasons and the scale should be the key scale to explore the habitat requirements of the pheasant, and to help conserve the pheasant more accurate and effective (Frost et al, 2001).

\section{References:}

Badyaev AV, Martin TE, Etges WJ. 1996. Habitat sampling and habitat selection by female Wild Turkeys: Ecological correlates and reproductive consequences [J]. Auk, 113: 636-646.
Because of the limitations of the habitat maps available, the classification of conifer forest was different between these two scales and one is the conifer forest and the other included the pine forest and fir forest. A common tendency, however, was discovered in the two scales, i.e. the conifer forest was preferred by this pheasant, and it might be of importance to this species. Fang \& Ding (1997) also concluded this result. As a result of forestry production, parts of the natural habitat in this region have been replaced by conifer forest (Xu et al, 2007), and it could have a significant effect on the population demographics, behavior, habitat selection, action model, reproduction, and abundance (Humes et al, 1999; Grialou et al, 2000).

To conclude, our results suggested that vegetation features and landscape structure were important habitat factors influencing breeding habitat selection of Reeves's Pheasant. However, the conifer forest and farmland are the most important impact factors for the habitat selection of the pheasant in breeding seasons. Therefore, some measures were recommended to conserve this pheasant, including strengthening the conservation of existing suitable habitat, controlling the development of farmland, and optimizing landscape configuration. Moreover, it also highlighted the importance of initiating research on the conifer forests, habitat structure, and their impact on the population of Reeves's Pheasants at landscape scale, which would be beneficial in promoting habitat conservation of this pheasant more effectively.

Acknowledgements: This work was supported by the National Sciences Foundation of China (30800103) and the National Key Project of Scientific and Technical Supporting Programs Funded by Ministry of Science \& Technology of China (2008BADB0B01). The provincial government and the management bureau of Dongzhai National Nature Reserve granted permission for this study. We thank RUAN Xiang-Feng, GAO Zhen-Jiang, and DU Zhi-Yong for their assistance during field work. We wish to acknowledge LIU Lin-Shan and ZHANG Wei of CAS, Prof. WANG Yong of America Alabama A \& M University for the GIS application and data analysis.

Boyce MS, Vernier PR, Nielsen SE, Schmiegelow FKA. 2002. Evaluating resource selection functions [J]. Ecol Modelling, 157: 281-300. 
Brickle NW. 2002. Habitat use, predicted distribution and conservation of peafowl (Pavo muticus) in Dak Lak Province, Vietnam [J]. Biol Conserv, 105: 189-197.

Burnham KP, Anderson DR. 1998. Model Selection and Inference: A Practical Information: Theoretic Approach [M]. New York: Springer-Verlog, 76-81.

Burnham KP, Anderson DR. 2002. Model Selection and Multimodel Inference: A practical information-theoretic Approach (second ed.)[M]. New York: Springer.

Cheng TH, Tan YK, Lu TC, Tang CZ, Bao GX, Li FL. 1978. Fauna Sinica, Aves Vol.4: Galliformes [M]. Beijing: Science Press, 173-175.

Cheng TH. 1987. A Synopsis of the Avifauna of China [M]. Beijing: Science Press. 167.

Cody ML. 1985. Habitat Selection in Birds [M]. New York: Academic Press.

Fang CL, Ding YH. 1997. The winter ecology of Reeves's Pheasant (Syrmaticus reevesii) [J]. Chn J of Ecol, 16 (2): 67-68. (in Chinese)

Frost TM, Ulanowicz RE, Blumenshine SC, Allen TFH, Taub F, Rodgers, JH Jr. 2001. Scaling issues in experimental ecology: freshwater ecosystems [M]//Gardner RH, Kemp WM, Kennedy VS et al. Scaling Relations in Experimental Ecology. New York: Columbia University Press, 253-580.

Graves GR. 2002. Habitat characteristics in the core breeding ranges of the Swainson's Warbler [J]. The Wilson Bulletin, 114(2): 210-220.

Grialou JA, West SD, Wilkins RN. 2000. The effects of forest clearcut harvesting and thinning on terrestrial salamanders [J]. $J$ Wildl Manage, 64: 105-113.

Hill DA, Robertson P. 1988. Breeding success of wild and hand reared ring-necked pheasants [J]. $J$ Wildl Manage, 52(3): 446-450.

Hosmer DW, Lemeshow S. 1999. Applied Logistic Regression [M]. New York: John Wiley \& Sons.

Hu XL, Wang S. 1981. A study on the ecology of Reeves's Pheasant [J]. Chn Wildl, 4: 39-44. (in Chinese)

Humes ML, Ha-Ms JP, Collopy MW. 1999. Bat activity in thinned, unthinned, and old-growth forests in western Oregon [J]. $J$ Wildl Manage, 63: 553-561.

IUCN. 2009. 2009 IUCN Red List of Threatened Species [M]. http://www.iucnredlist.org. Downloaded?on 10 December 2009.

Johnsgard PA. 1999. The Pheasant of the World: Biology and Natural History [M]. Washington: Smithsonian Institution Press.

Kotliar NB, Wiens JA. 1990. Multiple scales of patchiness and patch structure: A hierarchical framework for the study of heterogeneity[J]. Oikos, 59: 253-260.

Orians GH, Wittenberger JF. 1991. Spatial and temporal scales in habitat selection[J]. The Am Nat, 137: S30-S49.

MacKinnon J, Meng S, Carey C, Zhu X, Melville D. 1996. A Biodiversity Review of China [M]. Hong Kong: WWF International China Programme.

McGrath MT, DeStefand S, Riggs RA, Irwin LL, Roloff GJ. 2003. Spatially explicit influences on northern goshawk nesting habitat in the interior Pacific Northwest [J]. Wildl Mono, 154: 1-63.
Salafsky N, Margoulis R, Redford KH, Robinson JG. 2002. Improving the practice of conservation: a conceptual framework and research agenda for conservation science [J]. Conserv Biol, 16: 1469-1479.

Smith SA, Stewart NJ, Gates JE. 1999. Home ranges, habitat selection and mortality of Ring-necked Pheasant (Phasianus colchicus) in north-central Maryland [J]. The Am Midl Nat, 141 (1): 185-192.

Sun QH, Zhang ZW, Ruan XF, Zhang KY. 2001. Studies on flocking behavior of Reeves's Pheasant in Dongzhai Nature Reserve, Henan province [J]. J Beijing Normal Univ (Nat Sci Ed), 37: 111-116. (in Chinese with English Abstract)

Sun QH, Zhang ZW, Zhu JG, GAO ZJ. 2002. Roosting behavior and factors affecting roost-site used by Reeves's Pheasant (Syrmaticus reevesii)[J]. J Beijing Normal Univ (Nat Sci Ed), 38 (1): 108-112. (in Chinese with English Abstract)

Sun QH, Zhang ZW, Zheng GM, Zhang KY, Ruan XF, Zhu JG. 2003. Ranging behavior of territorial male Reeves's Pheasants in the breeding season[J]. Acta Zool Sin, 49 (3): 318-324. (in Chinese with English Abstract)

Wu ZK, Li ZM, Wang JH. 1994. Progress in research on Reeve's Pheasant in China [J]. Annl R World Pheasant Assoc, 39-43.

Xu JL, Zhang XH, Sun QH, Zheng GM, Wang Y, Zhang ZW. 2009. Home range composition, daily movement, and site fidelity of male Reeves's Pheasants Syrmaticus reevesii at a managed reserve in the Dabie Mountains, central China [J]. Wildlife Biol, 15: 338-344.

Xu JL, Zhang XH, Zhang ZW, Zheng GM, Ruan XF, Zhang KY. 2005. Home range and habitat use of male Reeves's Pheasant (Syrmaticus reevesii) in winter in Dongzhai National Nature Reserve, Henan Province [J]. Biodiversity Sci, 13: 416-423. (in Chinese with English Abstract)

Xu JL, Zhang XH, Zhang ZW, Zheng GM, Ruan XF, Zhu JG. 2006. Multi-scale analysis on wintering habitat selection of Reeves's Pheasant (Syrmaticus reevesii) in Dongzhai National Nature Reserve, Henan Province, China [J]. Acta Ecol Sin, 26: 2061-2067. (in Chinese with English Abstract)

Xu JL, Zhang XH, Zhang ZW, Zheng GM. 2002. Brood habitat characteristics of Reeves's Pheasant (Syrmaticus reevesii) in Dongzhai National Nature Reserve [J]. Zool Res, 23: 471-476. (in Chinese with English Abstract)

Xu JL, Zhang ZW, Zheng GM, Zhang XH, Sun QH, McGowan P. 2007. Home range and habitat use of Reeves's Pheasant Syrmaticus reevesii in the protected areas created from forest farms in Dabie Mountains, central China[J]. Bird Conserv Int, 17: 319-330.

Xu WS, Wu ZK, Li ZM. 1991. Reeves's Pheasant (Syrmaticus reevesii) $[\mathrm{C}] / / \mathrm{Lu}$ TC, Liu RS, He FQ. The Rare and Endangered Gamebirds in China. Fuzhou: Fujian Science and Technology Press, 328-338. (in Chinese with English Abstract)

Zheng GM, Wang QS. 1998. China Red Data Book of Endangered Animals (Aves) [M]. Beijing: Science Press. (in Chinese)

Zhang XH, Xu JL, Zhang ZW, Xie FL, Zhang KY, Zhu JG. 2004. A study on the incubation behaviur of Reeves's Pheasant (Syrmaticus reevesii) by radio tracking [J]. J Beijing Normal Univ (Nat Sci), 40(2): 255-259. (in Chinese with English Abstract) 